\title{
'Almost within Cooee': The Implications, for Sole-parent Families Living beyond Melbourne's Suburban Edge, of Long-term Poverty and 'Duty'-based Interventions
}

\author{
Tass Holmes \\ School of Social and Political Sciences, The University of Melbourne, Parkville Melbourne, 3010, Victoria, Australia
}

Copyright $\bigcirc 2018$ by authors, all rights reserved. Authors agree that this article remains permanently open access under the terms of the Creative Commons Attribution License 4.0 International License

\begin{abstract}
Recognising and theorising poverty is a difficult task in Australia, which is among the world's wealthy nations. This paper describes incidental findings of contemporary Australian poverty experiences, mainly affecting sole parents, from a recent ethnographic research in 'Sephirah', a fictitious inner-rural Victorian community. The encompassing study investigated usage of Complementary and Alternative Medicine (CAM) by a group of low-income Australians, who were generally unable to afford to consult with professional non-biomedical health providers. Anthropological participative research methods enabled basic statistical representation of households in a poor area, and documentation of health practices and beliefs, while in-depth interview narratives described the participants' experiences of a 'poverty status'. In conjunction with financial hardship, perceived difficulties arose from structured forms of discrimination, primarily impacting sole parents and their children, as the poorest subgroup among those enmeshed in long-term poverty, and secondly, mentally ill persons. These impoverished community members, in rural towns beyond Melbourne's peripheral suburbs, had few employment and educational opportunities, and limited support services. They describe impacts of morally-informed policy and welfare enactments by government, churches, and the health system, based on an idealised discourse that attributes seemingly unnecessary and destructive interventions to a doctrine of 'duty-of-care'.
\end{abstract}

Keywords Anthropology, Australian Welfare Policy, Sole Parent Poverty, Child Protection, Mental Health, Human Rights, Rural Demographics

\section{Introduction}

'Tackling inequality is a political choice, not an economic problem.

Richardson and Denniss, 2014, p.2.

'In this field there is too much policy-based "evidence", and too little evidence-based policy.'

Parkinson, 2013, p.7

'Public policy affecting those who cannot fend for themselves is the main determinant of the numbers who are in poverty.'

Richardson and Denniss, 2014, p.19.

This paper reports on impacts of hardships, long-term poverty, and institutional interventions faced by residents in a low-income community known as 'Sephirah', located beyond Melbourne's outer suburbs, in Victoria, Australia.

Drawing on recent ethnographic research, the author particularly seeks to describe the poverty experiences of sole parents, with the aim of highlighting the generally unrecognised and compound nature of the difficulties faced by the majority of sole parents, and their children, in Australia today. This circumstance is occurring on account of substantial welfare payment reductions some few years ago, that specifically targeted sole parents, and stigmatising enactments of duty-based policy approaches, delivered through job search agencies, churches, and branches of the healthcare system. It reflects a dominant conservative political agenda in Australia in recent years that has undermined budding efforts to alleviate poverty.

The umbrella research project that provided data to inform this discussion was focused on the persistent use of Complementary and Alternative Medicine (CAM) by low-income rural-dwelling health consumers in the state of Victoria, in South-East Australia. Findings of the research that describe such CAM use are documented elsewhere [1,a,b,c-2]. Briefly, the group of small-town and rural-dwelling interviewees could not afford private health 
insurance, or visits to CAM practitioners, and were therefore limited in obtaining professional CAM advice and treatments. Despite this, many types of CAM remained popular among the participants, whose interest in traditional, cultural and spiritual beliefs served as a justification for choosing CAM as part of their healthcare. Many exercised creativity in their sourcing of 'natural' and community-based approaches to healing.

The data of the research strongly highlighted the prevalence and long-term nature of poverty in this inner-regional community, particularly affecting sole parents. These findings are highly relevant to a contemporary strand of academic literature that challenges the value of neo-liberalist policies and governance, in causing increased poverty and related socio-economic hardship.

The literature overview in the following section provides a background and context for the presentation of condensed ethnographic data, further below.

\section{Literature Overview: Context}

\subsection{Poverty in Australia, and Interventions}

Beyond simple unemployment, low wages, or limited work hours, resulting in lack of disposable income [3-5], poverty among Australians often arises from personal or family problems, including exposure to domestic violence, family breakdown, and mental ill health. These problems bear particular relevance to many sole parents' circumstances [6-10]. Poverty of Australian children is linked to parental economic status [8] and has continued to increase for over a decade $[11,3]$. Sole parents' ability to afford household expenses is compromised by the recent history of serial reductions in Centrelink welfare payments, from the Howard through to Gillard prime-ministerships [12-16], with further cuts more recently suggested $[17,18]$. Successive conservative federal government leaders have expressed disinterest in sole parent families' welfare [14,16,18-20]. Additionally, despite people of limited means often now choosing to move due to unaffordable urban rental prices [21,22], to peripheral locations, including the community described in this research, the general costs of living, foods, health access, vehicle transport, and heating or cooling are often higher in non-metropolitan areas [23].

Further complications for sole parents occur due to the social and health policy enactments that are imposed by government agencies and other institutions. Combined with welfare reductions, directed ostensibly toward stimulating increases in sole parent labour-market participation (see: McArthur et al., 2013; Stevenson, 2015, p.97) [15,24], an institutionalised targeting of sole parents by government and church agencies comprises a form of entrenched structural discrimination which remains poorly recognised in the Australian context.
This paper contributes to literature on this topic by providing a 'real world' view from a relatively poor inner-rural community, with mediocre services access, and thereby illuminates common and stigmatising poverty experiences, which are seldom discussed.

\subsection{Brief overview of Australian Welfare Poverty as it Affects Sole Parents}

Australia's usual middle-class image, its mainly urban residential zones, and assumed wealth, serve to invisibilise welfare recipients who subsist on low and very low incomes (including sole parents, unemployed, youth/ students, elders, mentally ill, other disabled, and many Aboriginal persons and recent migrants). This is particularly the case in non-metropolitan places. Australian poverty is not completely unrecognised in academia. However, the challenges of life for Indigenous, disabled, elders, and for rurality in general, are much more clearly delineated than circumstances of other low-income groups [25-28]. Information about ongoing impoverishment of welfare-dependent sole parents, many with inadequate partner or family supports, remains relatively obscure (cf. long-term issues faced by sole parents post-separation are not specifically addressed in Hayes and Higgins' 2014 text [29], Families, Policy and The Law: Selected essays on contemporary issues for Australia, that aims to address changed/changing family structures).

Australia's poverty line is defined as half the median annual income [30], that is, presently, about \$26,000 AUD per annum for employed individuals. Income is substantially less than this for many welfare recipients, especially single unemployed persons without pensions, which today includes a majority of sole parents. Julia Gillard's federal Labor government (2010-2013) in 2012 enforced a reduction of sole parent welfare [31], that was first initiated in 2006 by John Howard's Liberal conservative government $[12,13]$. This change reduced sole parent pensions, for those with school-aged children, to a level approximating Newstart, a substantially lower payment [14]. Newstart formerly assumed no dependents. Sole parents, mainly women, were already Australia's poorest households, often living with poverty long-term, and having the lowest household incomes per number of persons. Sole parents (and tangentially elderly persons) have a recognised greater difficulty securing and holding jobs than other population groups (see: DSS, 2015, p.15, re 'middle tier' job-seekers; Robinson, 2009; McArthur et al., 2013) $[32,9,15]$ due to parental responsibilities. Research also suggests that women, and children, live much more frequently in poverty than men $[33,8]$.

While Gillard had expressed sympathy for workingclass and disabled persons, Howard claimed to be reducing poverty. Nevertheless, although an undesirable image of 'welfare mothers' had been prevalent as a recent theme in Australian mass media, noted by Wolfinger [13] and 
Crawford [14], and a neoliberal focus pressuring for greater individual responsibility for economic participation is also evident, the actual reason for dramatically limiting sole parent payments in either Gillard's or Howard's case remains unclear, and presents as punitive, morally harsh, discriminatory, and causing of needless hardship. This 'new' direction in Australian welfare policy apparently derives from a covert or inexplicit resentment on the part of government decision-makers toward sole parents (mainly women), based on a gender-biased, and stereo- typed idea of sole parents as non-normative and irres- ponsible 'flawed economic citizens' [13,24] (for example: Wolfinger, 2014, p.4). These flawed citizens cannot 'selfactualise' and provide sufficiently for themselves and their children within a striving neoliberal economy that fails to reflect on its own inequities [5]. Thus, through sole parents' ostensibly faulty and generally female 'dependent' behaviours, and their failure to perform the unrealistic socio-economic expectations of a modern 'good mother' (Stevenson, 2015, pp.98-99) [24], they come to be perceived as a contemporary social burden due to their necessary reliance on state funds. To some extent, this also mirrors a common sentiment among a percentage of disgruntled post-separation fathers, some of who, faced with legal changes that secured child maintenance payments from them [34] (ALRC 2011, rubrics 18-22) position themselves on a similar attitudinal footing to conservative state policy engineers. A disregarding of the daily workload involved in sole parenting, and of the obvious need for sole parents to utilise welfare payments, family payments and child support moneys for childrearing purposes, creates a reactive stance on the part of some fathers. Reductions in sole parent payments stands in stark contrast to the ethos of child support paid to reduce poverty, and also contrasts with marginally increa- sed welfare rates overall, and extensive federal government-funded increases in institutional support services, recently provided for disabled, elders and mentally ill welfare recipients, by Gillard and formerly by Howard (Kendig and Duckett, 2001, pp.12-16; Littlefield, 2015; Buckmaster, 2012) [35-37]. Widespread contemporary sole parent hardship thus bears witness to a sexist discriminatory attitude that continues to be levelled at women in Australia, particularly in the role of mothers. Wolfinger suggests [13] (p.8) that ways social problems such as sole parent poverty are defined and addressed by politicians, as a state of unemployment or non-participation, and by activists as a vulnerable state such that welfare payments are recognised as a social right, and also by the media, as women's oppression or conversely their burdensomeness to society, and purported lack of responsibility, all combine to limit or regulate discussion, and may bring about a failure to grapple with the problem of real social and economic disadvantage.

The idea of promoting sole parent employment (being relatively unrealisable in any case beyond urban zones), is an unlikely outcome from a strategy of reducing welfare payments [3, 38, 39]. Reduced welfare is furthermore understood to aggravate sole parents' mental health, as postulated by Brady and Cook [40], and to substantially increase poverty of children in sole-parent families, noted by Harding et al. [41]. Women's greater participation in employment happens to be occurring coincidentally with increasing casualisation, reduced hours of work, lack of job security, 'time poverty' and an entrenched 'glass ceil- ing' that obstructs advancement $[24,42,43]$. It can result in welfare payment reductions 'against earned income', that culminates in an ongoing poverty cycle despite employment [14]. In addition, many sole parents are unable to obtain work that fits around primary school hours. Resulting extreme poverty of sole parents (Phillips, Miranti, Vidyattama et al., 2013, pp.11-12; ACOSS, 2014, p.10) [44,33], now a reality for many contemporary Australian families, thus may lend extra fuel to the myth of sole parents being unable to cope or provide adequately for their children.

The apparent 'cost-cutting' achieved by federal governments in reducing sole parent payments, 'as a deterrent', or 'to save money', while concurrently spending vast sums, for example, on other welfare-dependent populations, built environment projects, and expensive military equipment [45-47], is decried on an international level as a violation of human rights (see Goldblatt, 2014) [48] that remains inadequately challenged.

Unfortunately the 'employment-promoting' payment reductions, rather than relieving poverty for Australia's poorest (non-refugee) population group, compromises previous efforts to alleviate hardship and poverty in the sizeable and still growing sole parent sector (see: Whitlam Institute, 2015; McClelland and St John, 2006, pp.183, 185) $[49,50]$. Lower income accentuates other problems faced by these many families, approximating $15-36 \%$ of urban families with child and/or teenage dependents, and $25-48 \%$ or more in rural-regional areas, varying by place [51]. In consequence, the present economic situation of Australian welfare-dependent sole parents is extremely disadvantageous, and this is occurring within an effective policy blind spot. There is, furthermore, a failure to distinguish the issues faced by partnered (rather than unpartnered) unemployed mothers, and the disadvantages faced by 'disabled' persons, from the current experience of extreme hardship among sole parents, many of whom must also contend with limitations to family support networks in addition to extreme financial restrictions.

\section{Methodology}

This research was conceptualised as anthropological, both in its descriptive intent and its participative mode of conduct. Data collection for the research entailed ethnographic documentation, based on participant observation 
activities in the study community in Victoria state, Australia, and in-depth interviews with 51 people.

The inner rural townships where fieldwork took place have been titled 'Sephirah' in published materials. The location is situated approximately one hour's drive beyond the outer margins of suburban Melbourne. Ethics clearance from the University of Melbourne permitted fieldwork to take place, from 2011 to 2013. The intention was to document popular health practices and beliefs regarding wellbeing, reflecting the original research aim.

Formal interviewees were recruited using a purposive snowballing method, mainly reliant on word-of-mouth recommendation, in order to select low-income respondents, who also had an abiding interest in CAM. Interview questions further explored the influence of rural residence, poverty, and low socio-economic status generally. Overall, both the CAM research respondents and the community as a whole had a median middle-aged and older demographic. A simple anonymous survey was also completed, documenting households in a poor segment of the community, and describing the extent of localised poverty and the character of impoverished families.

The combined data yielded a wealth of information about participants' challenging financial circumstances.

As this paper highlights, the implications of these findings reach beyond a simple view of the unaffordability of private-sector healthcare, including profession- al CAM services, and in fact serve to challenge the acceptability of a range of policy-based interventions directed towards Australian sole parents. The passages below rely on descriptive data to unpack the significance of sole parent poverty, and to describe their encounters with normative judgements and moral policy directives.

\section{Results}

\subsection{Community Demographics and Life-stories}

\subsubsection{Neighbourhood Poverty}

Among all surrounding communities, Sephirah was found to have the highest number of markers of specific disadvantage [52]. It had many sole-parent households, consistently high rates of unemployment, many long-term recipients of Newstart Allowance (Unemployment Benefit), low wages and limited income from businesses, professions and superannuation, a prevalence of maledominated unskilled work roles, onerous commuting times for urban employment, and problems of 'food insecurity' and high living expenses. During the 2006 Census, $40.8 \%$ of Sephirah residents claimed individual incomes less than the poverty line (then under $\$ 400$ AUD per week); this figure increased (as did the poverty line) by the 2011 Census [51,30]. Crime was relatively uncommon, although tragic road accidents frequently involved alcohol-affected young drivers and passengers. Many local residents lived in familiar communities close to where they grew up, and formed enmeshed social networks, despite financial disadvantage and lack of cultural opportunities, as has been described by Warr (2005) [53], in a study of Geelong neighbourhoods.

This author's anonymous survey of 70 properties (69 of them inhabited) in adjacent streets within a former public housing cluster, showed residents often lived in poverty for decades, experiencing familial and health issues as a consequence. Sole-parent families comprised 26.1\% $(18 / 69)$ of the surveyed households group, and were the poorest, with $77.8 \%(14 / 18)$ living in poverty all or most of the time. Two of the 18 sole parents were men; 16 were women. At least $38.9 \%$ (7/18) consumed anti-depressant medications for long periods or had other diagnosed mental illness. Although most houses, $84.1 \%$ (58/69), were owner-occupied, seven of 11 rental houses in this group were occupied by sole-parent families. Sole-parent households had the lowest incomes, and highest housing costs relative to income.

Employed single-person households, and partner-headed households with one or both partners employed, comprised only $47.8 \%$ (33/69), and employment was mostly lowpaid, often labouring, and some volunteer work. A majority of households, at least $55.1 \%(38 / 69)$, had adult members (excluding youth and teenagers) who currently relied on Centrelink benefits at that time, or had until recently received welfare payments for a number of years. Only three households $(4.35 \%)$ had members with trade qualifications, and all known post-secondary training and tertiary learning represented only $26 \%(18 / 69)$ of households. Children often lived in impoverished households. Adults in at least $17.4 \%(12 / 69)$ of the households experienced depression and/or mental illness ( 7 were sole parents). Premature adult deaths were frequent, affecting $7.25 \%(5 / 69)$ of these households during the fieldwork period alone (with others excluded, beyond this period).

\subsubsection{Impoverished Participants' Lives}

Interviewees, particularly sole parents, often lived with long-term poverty and had lives marked by hardship. Poverty themes included transport and access problems, and managing heavy chores alone, general high costs of living, and the difficulty of overall lack of funds and employment.

Marie, for example, was a former sole parent who lived alone, semi-retired at 62 years old, on a road distal to public transport services. Her savings from previous employment "dried up" after paying rent for a 2-bedroom cottage in a built-up area. After "a history of income fluctuations", she accepted Newstart, despite preferring to avoid Centrelink. Work was difficult to procure at her age.

Anna-Karina was a 53 year-old long-term sole parent, renting a tiny, dark, one-bedroom cottage with her youngest (teenage) daughter. Having been partnerless for decades, she had lost many treasured possessions when fire 
danger forced her to evacuate a former rental home.

39 year-old Minnie had been a sole parent since teenage, which forced her to leave school early and live on sole parent payments. Now on long-term medication for depression, she received disability support pension (DSP) and moved between a one-room flat in a city rooming house and a caravan behind her adoptive mother's home.

\subsubsection{Alternativity and a 'Low Footprint'}

Some sole parent interviewees embraced an alternative low-footprint lifestyle that helped reduce costs.

58 year-old Louisa was subsisting only on a Centrelink Widow's Allowance (equal to Newstart), following years of sole parenting, in a low-energy house on her bush property. She valued the idea of 'down-shifting' as part of a holistic worldview.

Cindy, a 32 year-old sole mother with pre-school aged children, paid rent out of her sole-parent welfare and family payments. Her ex-partner was unsupportive, but she enjoyed other close local friendships, valued ecological conservation, and espoused alternative views. She considers herself "a conspiracy theorist" who queries the trustworthiness of global profit-making industries.

Beanie-clad Helaina, age 61, had experienced poverty for decades as a sole parent of four children, the youngest with Downe's syndrome. She drove a small older-model car, often providing lifts for her ex-husband, who had mental health issues. Helaina was recently medicated herself for resurgent psychosis and depression from the past, but preferred to describe this experience in relation to her spiritual beliefs, about altruism, "psychic connectedness", an earth-mother Goddess figure, and the significance of transcendental revelations.

\subsection{Welfare and agency interventions:}

\subsubsection{Challenges for Women Stigmatised in a Sole-parenting Role}

Several sole parent participants in a weekly discussion group, 2013, titled 'Soul Parents Relationship to Work' (SPRW), were aged between 36 and 53. They described experiences of stigmatisation and social alienation, including policies and comments that suggest single mothers are, in the words of 47-year old convenor, Poppy, "irresponsible, lazy or unwilling to try". Some women had been called "dirty" if unskilled at housework; others were implied to be promiscuous, or were cast as "outsiders" or "deviants", or were "suspected of avoiding work" and of "deliberately rorting the welfare system". Some felt they had been portrayed as inherently "nasty, or useless in some way", with all this supposedly explaining how they had "fallen into" becoming sole parents. Often having left violent relationships, and surviving on the currently reduced Parenting Payment Single (PPS/Newstart), they found it inconceivable that their struggle could be construed as "ripping off the system". Such limited funding cannot compass even the basic costs of living for an adult with children.

Three of the seven group members documented had mental illness diagnoses, while others had either physical degenerative illness with unmedicated self-identified depression, or chronic fatigue and frequent severe pain. Their feelings of depression, harassment by ex-partners, loneliness, and the unremitting poverty and chores attendant on sole parenting were further complicated for some by the high costs of accommodation and insecure tenancies. All felt forced to carry heavy family responsibilities beyond their capability, for several to many years, were tied to home-based family work, and were unable to "simply go out and work" in paid jobs. With children at school during the day, commuting to urban jobs was overly time-consuming, and some faced additional responsibilities for care of elders and/or other extended family members. None had re-partnered, and most received little or no assistance from ex-partner(s).

Given the hardships of sole parenting, its role in limiting employment, and usual persistence for decades of many women's lives, the approximate $\$ 100+$ per week welfare reductions, affecting all sole parents with school-age dependants, unnecessarily pushes most Australian sole parent families into dire poverty. ACOSS' 2012 report (p.8) [3] estimated $17.3 \%$ of children in Australia now live below the poverty line, many with sole parents [40], and are thus construed as being 'at risk'. The poverty of sole parent families has subsequently increased since that report [33]. Furthermore, the distribution of poverty among socially disadvantaged groups serves to create a stigmatising notion that poor persons are generally unintelligent, of low morals, or incapable of living a normal life [54].

\subsubsection{DHHS Child Removal as 'Duty-of-care'}

A glaring problem unfolds in relation to the 'at risk' designation of sole parents, in the form of over-frequent removal of children from sole parent households. Justified through child-protection discourse, and couched in structured policy frameworks, this pattern sees increased government funding geared to addressing concerns about child wellbeing. Scant sociological critique or acknowledgement exists about sole parents as common targets of Department of Health and Human Services (DHHS) child-removal practices (although novelist Lisa Unger: 2006, in Beautiful Lies [55] situates the problem historically in USA, directed at single ethnic-minority mothers). Indigenous people have experienced this problem as ongoing, such as in South Dakota [56]. Also in Australia, according to Australian Inst. of Family Studies statistics (2015) [57] Aboriginal child-removals affect $38.8 / 1000$ children, in contrast with non-Aboriginal children, who are removed from families at a low rate of 5.7/1000. Undue force is at times applied to remove Aboriginal children, for spurious reason, according to media reports, statistics, and critical policy reviews [57-59].

Ethnographic data from this research contextualises this 
problem in part also by positioning sole-parents and their children relative to the concept of 'duty-of-care' for healthcare settings. Following a SPRW meeting, PPoppy commented about the treatment, by staff in a specialist medical clinic, of herself and her 12 year-old daughter Phoebe, when they had sought help for Phoebe's mild but chronic health issue. Both were subjected to detailed questioning regarding unrelated aspects of their private life. Phoebe was further interrogated by an extra staff member, without permission or prior introduction, when Poppy had left the room briefly to re-park her vehicle. Poppy interpreted this as a reaction to her combined sole-parenting and home-schooling status, with questions implied as to whether Poppy herself (or another person) had abused Phoebe, to cause the health problem.

Similarly, incidences of 'independent', pragmatic healthcare decision-making by female sole parents, such as practical rural first-aid approaches when distal to a clinic or hospital - or conversely, experiences of 'stress', not coping, or confusion for some - was apparently often construed as 'noncompliance' on the part of a number of the sole parents, or as defiance of normative medical expectations of healthcare. Seemingly, health-workers who are motivated by moral readings of 'duty', are occasionally over-hasty to interpret sole parents as abus- ing a child. One very grief-stricken solo mum in the SPRW group narrated how her children were removed from her when - suffering mild confusion of mental ill- ness and depression but without abuse directed to her children - she was deemed 'unfit'. Thus, an unwelcome side-effect of psychiatric treatment amounts too often to loss of children to DHHS. Many parents most needy of supports are instead being simply labeled as inadequate.

Furthermore, while extensive and costly medical, bureaucratic and court systems are maintained [60], many needy families experiencing child-parental conflict are rarely provided with help beyond uncompromising DHHS assessments and stern 'contact' supervisions.

Five female sole parents encountered during the fieldwork, whose child/ren were removed, each fit one or more additional categories: of Aboriginality, teenage mother, diagnosed mental illness, or slow learner at school [61-64]. These women were, arguably, 'adequate' in a parenting role; according to their own representations they did not subject the children to direct abuse. Yet none were provided with social supports sufficient to enable them to 'keep' their children (as human rights and child protection legislation recommend) $[65,66]$. None of the removed children were later returned to their families. Yet the researcher encountered no incidences of married, de-facto or recently-separated parents 'losing' children to DHHS, although some such families faced issues of alcoholism or substance abuse, or were reported for sexual or violent physical assaults of their children. (Comparatively, some children had been removed by DHHS from families, prior to moving to Sephirah, at a time when the mother was unpartnered and/or not coping; these children were later returned to newly partnered mothers, again suggesting discrimination re sole parents.)

\subsubsection{Church Activities as 'Home-wrecking'}

Foucault has critiqued theoretically the grim nature of systemic state-based power and surveillance, that subjectifies citizens and seeks to suppress social or familial deviance [67, 68], as is very obviously the case in realms of child protection. Arguably, subjectifying power echoes even more strongly through morally-informed approaches of churches that become involved in child removals.

Data from this current contemporary research furnished descriptions of church-based family interventions. One 'fundamentalist' church pastor favoured removing teenage children from families, mainly boys, age 12 to 21 , to be placed in high-income religious families. Church counsellors, also, urged solo mothers to 'forgive' violent crimes perpetrated by partners or ex-partners, to ensure the continuity of fathers' contact with affected child/ren, while solo mothers were considered inadequate to provide parental care, thus requiring church 'support', which was easily translated into child removal.

One outer-suburban religious organisation servicing adjacent towns, assisted teenagers 'at risk of becoming homeless', including teens still living with their family, who claimed to be 'distracted at school', thereby eliminating any usual criteria of familial abuse. Caseworkers invoke clauses of 'duty-of-care' or 'client confidentiality' to avoid notifying or negotiating with the teenagers' parents, thereby contravening the letter of the law, as is clearly iterated by Douglas and Walsh (2009) [65], and bypassing usual requisite legal avenues outlined in state law [69]. Teenage clients' confidentiality may be upheld at the expense of current and future family relationships. One young woman who lived two years in the agency's youth housing cluster claimed the majority of resident teenagers at the time had first-generation migrant parents, with several originating from sole parent homes. They believed their mothers were "crazy" and "too poor". Hence, such church-managed child protection serves to negatively label affected parents, reinforcing an 'under- class' marginal identity [70] that results in long-term estrangement of removed teenagers from caring families.

Current protective child-removal practice, while morally grounded, also creates enormous annual costs (Australia's Productivity Commission (2015) [71] estimated $\$ 3.3$ billion during 2013-14), borne mainly by governments, to pay for youth accommodations, and wages or allowances for case-workers, foster-carers, and counselling and psychology services, as part of a self-perpetuating and self-justifying bureaucracy. Such practice does not however provide any support for parents, or promote family cohesion and rights outlined in legislation. Instead it 'targets' needy families, creating excessive grief and exacerbating the prevalent depression, and susceptibility to longstanding mental illness, that is being experienced all too often by sole mothers. 


\subsubsection{Early Deaths of Mentally-ill Persons}

Another apparently localised finding concerned a high number of premature adult deaths. These were often unexpected, causing significant family grief. Familiarity with several Sephirean sole parents with mental illness diagnoses caused concern for the researcher when the data implied a link between over-frequent early-adult $(<60$ years) local deaths, and the circumstances of some of the deceased, who were mental health consumers.

A group of twenty recent early-adult familiar local deaths were persons known either to a primary local informant, or the researcher, or both. Among these deceased, $70 \%(14 / 20)$ had regularly consumed prescribed medications, with or without other substance use (usually alcohol and cigarette-smoking), although not all recent community deaths could be listed for comparison. The suggested association between early-adult deaths and medications usage raised questions regarding a possible contributory role of prescribed sedatives and antipsychotics in early-adult health-consumer deaths especially during diagnosed mental illness. This finding warrants further investigation. Over-prescription of psychoactive and sedative medications can contribute to chronic physical unwellness and greater disability among mentally ill persons, while having a mental diagnosis itself reduces life expectancy by up to $20-25$ years, especially if combined with low-income $[72,73]$. Legal enforcement of medication regimes may, for some of these health consumers, heighten their sense of helplessness, disem- powerment and inescapable social stigma.

Although most causes of Australian premature deaths ( $<75$ years, in AIHW statistics) [74] have reduced, deaths from 'accidental poisonings' (ingestion of substances, including alcohol, narcotics, sedatives, anti-psychotics, antidepressants, or other medications or toxics) and 'mental-behavioural' deaths, both continue to increase in number and age-associated rates. They now represent a lead cause of mortality for both men and women below 45 years of age. Accidental deaths from non-illicit prescribed drugs (often anti-psychotics or antidepressants) among mentally-ill or non-'habitual' consumers of pharmaceuticals, while relatively common, are poorly recognised, in stark contrast to deaths caused by illicit drugs [75], which are still occurring at a low, but reducing rate [76]. There is however a growing rate of prescribed medication use, that tallies eerily with the still increasing rates of 'accidental overdose' deaths.

\section{Discussion}

This paper grapples with difficult issues of Australian poverty and policy, as they impact sole parents living in an inner-rural community in Victoria State. The research participants experienced entrenched poverty, and were acutely aware of how the implementation of moral directives and institutionalised duty-of-care compounded their problems, potentially feeding a downward spiral of depression and negative personal and family outcomes.

Research described in this paper found that sole parents (an estimated 1/4 of Australian families with children) were often frankly impoverished, unfairly stigmatised, 'depressed', medicated, chronically unwell, and faced extensive poverty and related challenges, such as insecure housing, lack of suitable social supports, long-term unemployment, cumbersome 'job-seeker' expectations, and being unfairly targeted by DHHS and church-based groups that cast doubt on their suitability as parents.

The seemingly deliberate and discriminatory underfunding of Australian sole-parent households by governments has been achieved through ill-considered and arguably unethical welfare reductions, alongside reduced public housing provision, extensive retraction of funding from charitable organisations and substantial dismantling of social support services. Meanwhile, the expansively-funded Department of Health and Human Services' removal of children from sole-parents (and ethnic minorities, including numerous Aboriginal families) who are held to be 'not coping' in parenting roles, does little to uphold recommendations outlined in legal and rights documents.

Any claim that the government needs to economise through reduced sole parent payments should be refuted. The author's estimated calculation of costs to reinstate 'full' pensions for all sole parents until children turn 16 years of age, amounted to $\$ 1.4$ to $\$ 1.9$ billion p.a., with extra family support services already factored in. This approximates only $20 \%$ of unpaid general tax each year in Australia [77], and a minute fraction of the $\$ 90$ billion tax revenues Australia neglects to collect from resource- extracting multinationals [78]. Oxfam claims Australia's "broken economic system" fares poorly in inequality measures, and is headed for a major inequity crisis [79].

\section{Conclusions}

Australia is a wealthy first-world country, one that ostensibly upholds human rights and prohibits discrimination, as is enshrined in its laws and in the fact of it being a signatory to international rights charters. Despite this, the range of policy-based interventions, and their devastating consequences, observed throughout this research, constitute a systematised and almost entirely gender-based form of structural discrimination. This represents a government-led attempt to exploit and to exert control over the lives, destinies, and choices of many Australian women, in their common and challenging contemporary role as poorly supported sole parents.

In closing, a further important realisation afforded by this research concerns the usefulness of ethnographic description for engaging with 'reality', in order to sidestep the habitual opacity of many statistical studies. 


\section{Acknowledgements}

The author is very grateful to all participants of the research, in particular numerous interviewees who willingly shared details of their lives during formal interviews and informal conversations.

\section{REFERENCES}

[1] Holmes, T. Experiences of Chinese medicine in a rural community. The Lantern: A Journal for Practitioners of Chinese Medicine. 12(3): 36-41. 2015a; Holmes, T. CAM use by rural Victorians: An introduction. Journal of The Australian Traditional Medicin Soc. 21(3): 176-179. 2015b; Holmes, T. Rural Naturopaths's Provision to Poorer Clients. Journ Aust Trad Med Soc. 21(4): 228-233. 2015c.

[2] Holmes, T. CAM use by poor rural Victorian consumers. Journal of Aust Traditional Med Soc. 22(1): 20-25. 2016.

[3] Australian Council of Social Service (ACOSS). Research Paper No.194. Poverty in Aust. Strawberry Hills: 2012.

[4] Barbato, C, Concannon, G, and Leppert, S. Life on a Low Income, 2006: State of the Family. Canberra: Anglicare Australia, 2006. Available, at July 2018, from: http:// www.anglicare.asn.au/docs/default-source/default-docume nt-library/sotf-2006-life-on-a-low-income.pdf?sfvrsn=2.

[5] Richardson, D, and Denniss, R. Policy Brief No.64. Income and Wealth Inequality in Australia. The Australia Institute. 2014. Available, as at July 2018, from: http://www.tai.org.au/system/files force/PB+64+Income+ and+wealth+inequality+FINAL.pdf.

[6] Kaspiew, R, Carson, R, Dunstan J, De Maio, J, Moore, S, Moloney, L, Smart, D, Qu, L, Coulson, M, and Tayton, S. Experiences of Separated Parents Study: Evaluation of the 2012 Family Violence Amendments. Melb: Aust Institute of Family Studies (AIFS). 2015: https://aifs.gov.au/ publications/experiences-separated-parents-study.

[7] Parkinson, P. Violence, abuse, and the limits of shared parental responsibility. Family Matters. Issue 92: 7-17. Melbourne: AIFS. 2013.

[8] De Vaus, D, Gray, M, Qu, L, and Stanton, D. Research Rpt 31: Economic consequences of divorce in six OECD countries. Austral Inst of Family Stud. Melb: AIFS. 2015: https://aifs.gov.au/sites/default/files/publication-documents /rr31.pdf.

[9] Robinson, E. (2009). Sole-parent families: Different needs or a need for different perceptions? Family Matters. Issue 82: 47-51. Melbourne: AIFS.

[10] Reupert, Maybery and Kowalenko. Children whose parents have a mental illness: prevalence, need and treatment. Medical Journ. of Aust. Open 1, Supplement 1: 7-9. 2012.

[11] Chadwick, V. Single-parent families struggling to survive. Canberra Times. 2013 (12th Jun). Available from: http://www.canberratimes.com.au/opinion/political-news/s ingleparent-families-struggling-to-survive-20130611-2o28 k.html.
[12] Summerfield, T, Young, L, Harman, J, and Flatau, P. Child Support and Welfare to Work reforms: The economic consequences for single-parent families. Family Matters, Issue 84: 68-78. Melbourne: AIFS. 2010.

[13] Wolfinger, E. Australia's Welfare Discourse and News: Presenting Single Mothers. Global Media Journal, Australian edition. 8(2): 1-16. 2014. Available from: http://www.hca.westernsydney.edu.au/gmjau/?p=1543.

[14] Crawford, A. This Isn't Working: Single Mothers and Welfare. Meanjin. 73(3): 1-16. 2014. Available from: https://meanjin.com.au/essays/this-isnt-working-single-mo thers-and-welfare/.

[15] McArthur, M, Thomson, L and Winkworth, G. Jumping through hoops - the cost of compliance on sole parents. Child \& Family Social Work. 18: 159-167. 2013.

[16] Cater N. Columnist opinion: Welfare system reform must be clever. The Australian. 2015 (29 ${ }^{\text {th }}$ Sep). Last retr. 2016.

[17] Coleman, M. The FTB cuts have been softened, but they're still a con. The Drum: ABC online. 2015 (23rd Oct). Availabl: http://www.abc.net.au/news/2015-10-23/coleman -the-ftb-cuts-have-been-softened,-but-they're-still-a-con/68 78498 .

[18] Bryce, J. Centrelink welfare cuts government targets single parents again: Turnbull proposing to cut $\$ 48$ a week from single parents. In SingleMum.com.au. 2016. Available fr: http://centrelink.singlemum.com.au/single-parent-payment -welfare-single-parents-26022016-jason-bryce.html\#.

[19] Borrello, E, and Keany, F. Govt introduces legislation to scale back Family Tax Bft pmts. ABC News 201522 Oct: http://www.abc.net.au/news/2015-10-21/government-to-sc ale-back-family-tax-benefit-payments/6871524.

[20] Yaxley, L. Low-income families to bear brunt of federal budget reforms, Labor modelling shows. ABC News. 2015 (25th May). Available from: http://www.abc.net.au/news/2 015-05-25/labor-figures-show-families-to-bear-brunt-of-bu dget $/ 6493500$.

[21] Vedelago, C. Soaring rents fuel city's poverty crisis. The Age. 2010 (3rd Oct). Available from:

http://www.theage.com.au/victoria/soaring-rents-fuel-citys -poverty-crisis-20101002-1621z.html.

[22] Browne, R. Renters being driven further from the city. Sydney Morning Herald. 2015 (4th Nov). Last retrieved Nov 2015. / Browne, R, Wade, M. The price of being a global city: Sydney's rent crisis. SMH. 2015 (28th Nov) Available:http://www.smh.com.au/nsw/the-price-of-beinga-global-city-sydneys-rent-crisis-20151126-g191py.html.

[23] Palermo, C, and Smith, C. (Eds.). Report: Outer East Community Food Access Research Project: Food Security Assessment and Plans for a Way Forward. Ringwood, Victoria: Outer East Health, Community Support Alliance, and Monash University. 2009.

[24] Stevenson, L. Working Mothers in Neoliberal Times. In The Annual Conference of The Australian Sociological Association: Neoliberalism and Contemporary Challenges for the Asia-Pacific. Refereed Proceedings, 96-103. 2015.

[25] Australian Gov Dept of Social Services (DSS). A New System for Better Employment \& Social Outcomes: Report 
of Ref Grp on Welfare Reform to Minister Soc Serv. 2015: https://www.dss.gov.au/sites/default/files/documents/02_2 015/dss001_14_final_report_access_2.pdf.

[26] Belardi, L. Fresh focus on old age poverty in Australia. Australian Ageing Agenda. 2014 (1st Oct). Available from: http://www.australianageingagenda.com.au/2014/10/01/au stralia-lags-behind-old-age-poverty/.

[27] Australian Human Rights Commission. (AHRC). A statistical overview of Aboriginal and Torres Strait Islander peoples in Australia. In AHRC website. 2006: https://www.humanrights.gov.au/publications/statistical-ov erview-aboriginal-and-torres-strait-islander-peoples-austral ia.

[28] Alston, M. (2000). Rural Poverty. Australian Social Work. 53(1): 29-34.

[29] Hayes, A, and Higgins, D. (Eds.) Families, policy and the law: Selected essays on contemporary issues for Australia. Melbourne: AIFS. 2014. Available from: https://aifs.gov.au/publications/families-policy-and-law.

[30] Melbourne Institute of Applied Economic and Social Research (MIAESR). Summaries: Poverty Lines, Australia. In Melbourne Institute, Labour Economics and Social Research website. University of Melbourne. 2015. Availab: https://melbourneinstitute.unimelb.edu.au/publications/pov erty-lines.

[31] ACOSS. UN asks Australian Government to explain violation of single parents' rights. ACOSS site. 2013: http://www.acoss.org.au/media_release/un_asks_australian government to_explain_violation_of_single_parents_right $\mathrm{s} /$.

[32] DSS. SHUT OUT: Experience of People with Disabilities \& Their Families in Aust. Canberra. 2009. Available from: https://www.dss.gov.au/sites/default/files/documents/05_2 012/nds_report.pdf.

[33] ACOSS. Poverty in Aust 2014 (4th ed). Strawb Hills. 2014.

[34] ALRC. Australian Law Reform Com. Child Support Laws. Family Violence \& Commonwealth Laws-Child Support and Family Assistance, IP38. Aus Gov ALRC web. 2011: http://www.alrc.gov.au/publications/family-violence $\% \mathrm{E} 2$ $\% 80 \% 94$ child-support-and-family-assistance/child-support -laws

[35] Kendig, H, and Duckett, S. Australian directions in aged care: the generation of policies for generations of older people. Sydney: Australian Health Policy Institute. 2001. Last retrieved July 2016, via AHPI/Dept of Health website. Abstract available from: http://apo.org.au/node/8493.

[36] Littlefield, L. Protecting Australians' access to effective mental health treatment under Medicare. Aust. Psycholog Society website. 2015. Last retrieved Jul 2016 from: https://www.psychology.org.au/inpsych/june/2015/ed/.

[37] Buckmaster, L. National Disability Insurance Scheme. Res. Paper No.9: Budget Review 2012-13. Parl Aus website. 2012: http://www.aph.gov.au/About_Parliament/Parliamen tary Departments/Parliamentary_Library/pubs/rp/BudgetR eview201213/NDIS

[38] Cook, K, and Noblet, A. Job satisfaction and 'welfare-towork': is any job a good job for Australian single mothers? Australian Journal of Social Iss. 47(2): 203-219. 2012.
[39] Cox, E. What the government wants to ignore about sole parents and job seeking. Conversation. 2013, 17th Jan, at: $\mathrm{http}: / /$ theconversation.com/what-the-governmentwants-to-ignore-about-sole-parents-and-jobseeking-11582.

[40] Brady, M, and Cook K. The impact of welfare to work on parents and their children. Evidence Base. 3: 1-23. 2015. Abstract available from :https://www.exeley.com/archive/2 $2 / 2015 / 3$.

[41] Harding, A, Vu, QN, Percival, R, and Beer, G. Welfare-To-Work Reforms: Impact on Sole Parents. Agenda. 12(3): 195-210. 2005.

[42] Probert, B. Mothers in the labour force: A step forward and two back. Family Matters. Iss.54: 60-65. Melb.: AIFS. 1999.

[43] Goodin, R E. Who's really time poor? Family Matters. Issue 87: 9-12. Melbourne: AIFS. 2011

[44] Phillips, B, Miranti, R, Vidyattama, Y and Cassells, R; NATSEM. National Centre for Social, Economic Modelling. (2013). Poverty, Social Exclusion and Disadvantage in Australia. Canberra: University of Canberra.

[45] Griffiths, E. Gillard brought to tears while introducing disab- ility legislation. $A B C$ News. 201327 Jun. Available: http://www.abc.net.au/news/2013-05-15/gillard-cries-whil e-introducing-disability-legislation/4690692.

[46] O'Sullivan, M. Highway robbery: Taxpayer money flows to transport projects in margin seats Syd M Her 20164 Apr: http://www.smh.com.au/nsw/highway-robbery-taxpayer-m oney-flows-to-transport-projects-in-marginal-seats-201603 31-gnuzm8.html.

[47] Doherty, B. F-35 Joint Strike Fighter purchase 'a great national scandal' Coalition MP Syd M Her. 2014 16Jun: http://www.smh.com.au/national/f35-joint-strike-fighter-p urchase-a-great-national-scandal-says-coalition-mp-20140 616-zs9po.html.

[48] Goldblatt B. Testing Women's Right to Social Security in Australia: A Poor Score. In Goldblatt B, Lamarche L. Women's Rights to Social Security and Social Protection. Chapters 13 and 10. Oxford: Hart Publishing. 2014.

[49] Whitlam Inst. 'Healthcare and Social Security'; 'Women and Social Reforms'. Whitlam Institute site. Western Syd University 2015. Retrieved July 2016, at: https://www.whitlam.org/gough_whitlam/achievements. See 'Healthcare and Social Security', now at: https://jenna-beck-f8w5.squarespace.com/whitlam-legacyhealthcare-social-security. 'Women and Social Reforms', is not now available from: https://jenna-beck-f8w5.squarespace.com/studying-whitla $\mathrm{m}$; but see instead: 'Women's Rights': https://jenna-beck-f8w5.squarespace.com/whitlam-legacywomens-rights.

[50] McClelland, A, and St John, S. Social Policy Responses to Globalisation in Australia and New Zealand, 1980-2005. Aust Journal of Political Science 41(2): 177-191. 2006.

[51] Aust Bur of Stats (ABS). Census Community Profiles 2011: http://www.abs.gov.au/websitedbs/censushome.nsf/home/c ommunityprofiles?opendocument\&navpos $=230$. 
[52] ABS. National Regional Profile 2004-2008: Victoria. Available via Index page, area data. 2010. Available from: http://stat.abs.gov.au/itt/r.jsp?databyregion.

[53] Warr, D. (2005). Social networks in a 'discredited' neighbourhood. Journal of Sociology. 41: 285-308.

[54] Rusch, N, Angermeyer, M, \& Corrigan, P. (2005). Mental illness stigma: Concepts, consequences, and initiatives to reduce stigma. European Psychiatry. 20: 529-539.

[55] Unger, L. (2006). Beautiful Lies. New York: Bantam.

[56] Sullivan, L. Native American tribes win child welfare case in South Dakota. NPR online. 2015 (31st Mar). Available: http://www.npr.org/2015/03/31/396636927/native-america n-tribes-win-child-welfare-case-in-south-dakota.

[57] AIFS. Resource Sheet: Child protection and Aboriginal and Torres Strait Islander Children. AIFS: Child Family Community Australia. 2015. Available from: https://aifs.gov.au/cfca/publications/child-protection-and-a boriginal-and-torres-strait-islander-children.

[58] Pilger J. Another stolen generation: how Australia still wrecks Aboriginal families. The Guardian. 2014 22nd Mar: http://www.theguardian.com/commentisfree/2014/mar/21/j ohn-pilger-indigenous-australian-families.

[59] Lamacraft, T. Police deny guns were drawn during removal of children from Moree homes. ABC News. 201416 Sep: http://www.abc.net.au/news/2014-09-16/police-deny-gunswere-pointed-at-family-when-children-removed/5746560.

[60] Hansen, P. and Ainsworth, F. Australian child protection services: A game without end. International Journal of Social Welfare. 22: 104-110. 2013.

[61] Boursnell, M. Assessing the capacity of parents with mental illness: Parents with mental illness and risk. International Social Work. 57(2): 92-108. 2014.

[62] Sheehan, R, and Levine, G. Parents with Mental Illness: Decision-making in Australian Children's Court Cases Involving Parents with Mental Health Problems. Journal of Social Welfare and Family Law. 27(1): 17-30. 2005.

[63] Mayes, R, and Llewellyn, G. Mothering differently: Narratives of mothers with intellectual disability whose children have been compulsorily removed. Journal of Intellectual \& Developmental Disability. 2: 121-130. 2012.

[64] Douglas, H, and Walsh, T. Continuing the Stolen Generations: Child Protection Interventions and Indigenous People. Internatnl Journal of Children's Rights. 21: 59-87. 2013.

[65] Douglas, H, and Walsh, T. Mothers and the Child Protection System. International Journal of Law, Policy and the Family. 23: 211-229. 2009.

[66] Ainsworth, F, and Hansen, P. The Experience of Parents of Children in Care: The Human Rights Issue. Child and Youth Services. 32: 9-18. 2011.

[67] Bell, S. Through a Foucauldian Lens: A Genealogy of Child Abuse. Journ of Family Violence. 26: 101-108. 2011.
[68] Wrennal, L. Surveillance and Child Protection: Demystifying th Trojan Horse. Surveill \& Soc. 7(3-4): 304-324. 2010.

[69] Victorian State Government, Aust. Current Acts: Children, Youth and Families Act 2005, Version No.44 (No.96/2005, Amendments $3^{\text {rd }}$ March 2014). 2005. Available from: http://www.austlii.edu.au/au/legis/vic/consol act/cyafa200 $5252 /$.

[70] Hyslop, I. Child Protection Policy and Practice: A Relationship Lost in Translation. Social Policy Journal of New Zealand. 34: 62-72. 2008.

[71] Australian Productivity Commission. Report on Government Services 2015: Chapter 15: Volume F: Child Protection Services. 2015. Available from: http://www.pc.gov.au/research/ongoing/report-on-governm ent-services/2015/community-services/child-protection.

[72] Laursen, T, Wahlbeck, K, Hallgren, J, Westman, J, Osby, U, Alinaghizadeh, H, Gissler, M, and Nordentoft, M. Life Expectancy and Death by Diseases of the Circulatory System in Patients with Bipolar Disorder or Schizophrenia in the Nordic Countries PLOS One 8(6): e67133:1-7. 2013.

[73] Martin, J, McLean, G, Park, J, Martin, D, Connolly, M, Mercer, S, and Smith, D. Impact of socioeconomic deprivat- ion on rate and cause of death in severe mental illness. BMC Psychiatry. 261: 1-10. 2014. Available from: http://www.biomedcentral.com/1471-244X/14/261.

[74] Australian Institute of Health \& Welfare (AIHW). Feature article. Ser. 14. Cat. AUS.178. 5.5 Illicit drug use: Current and future issues. Australia's Health 2014. Canberra. 2014.

[75] Roxburgh, A, Ritter, A, Slade, T, and Burns, L. (2013). Report: Trends in Drug Use and Related Harms in Australia, 2001 to 2013. National Drug and Alcohol Research Centre. Sydney: University of New South Wales.

[76] AIHW. Leading cause[s] premature mortality in Austr. All causes; Accidental poisoning; Suicide; Accidental drowning; Assault. Canb. 2015. Last retr. Oct 2015 from: http://www.aihw.gov.au/publication-detail/?id=601295527 22; now instead see 2016 version (or later) available by Google search, e.g. 'Australia's Health 2016, 3.2 Premature Mortality', available as a PDF for download.

[77] Bagshaw, E. $\$ 8$ billion in income tax lost each year. Sydney Morning Herald. 2018 (11 $\left.{ }^{\text {th }} \mathrm{Jul}\right)$. Available from: https://www.smh.com.au/politics/federal/8-billion-in-inco me-tax-lost-each-year-tax-office-concedes-20180711-p4zq sg.html.

[78] Bagshaw, E. 'Staggering': $\$ 90$ billion lost in resources tax. SMH. $2018 \quad\left(12^{\text {th }} \quad\right.$ Mar). Available from: https://www.smh.com.au/politics/federal/staggering-90-bill ion-lost-in-resources-tax-20180305-p4z2uv.html.

[79] Hutchins, G. Top 1\% Australians own more wealth than bottom 70\% comb Guardian. 2018 ( $\left.22^{\text {nd }} J a n\right)$. Available: https://www.theguardian.com/australia-news/2018/jan/22/t op-1-per-cent-of-australians-own-more-wealth-than-botto m-70-per-cent-combined. Oxfam Australia. Fact Sheet: Growing gulf between work and wealth. 2018. Available from:https://www.oxfam.org.au/wp-content/uploads/2018/ 01/2018-Davos-fact-sheets.pdf. 